\title{
有明海北西岸のクド造り民家の方位に及ぼす気候要因 EFFECTS OF CLIMATIC FACTORS ON THE ORIENTATION OF KUDO-ZUKURI HOUSES IN NORTHWEST AREA ALONG ARIAKE SEA
}

\author{
長野和 雄*, 堀越哲美 ${ }^{* *}$, 鈴木健 次***, 宇野勇治****, 兼子朋也***** \\ Kazuo NAGANO, Tetsumi HORIKOSHI, Kenji SUZUKI, \\ Yuji UNO and Tomoya KANEKO
}

\begin{abstract}
Kudo-zukuri is a vernacular house the roof of which is U-shaped in plan. The purpose of this study is to investigate what is behind the fact that the roof gaps of most kudo-zukuri houses in Kashima and Shiroishi of Saga prefecture face north-northeast. The wind roses derived from AMeDAS (Automated Meteorological Data Acquisition System) and AEROS (Atmospheric Environmental Regional Observation System) data show the prevailing winds come from northwest in winter and west-southwest in summer, and the northeast wind rarely blows. According to the survey materials with regard to the vernacular wind names by Sekiguchi (1985), the residents in Kashima recognize that west, northwest and south winds are strong or chilly. Thus for enduring the winds, the most appropriate direction of the roof gap is northeast. The mean depth of direct sunlight area into each main room at twenty-two kudo-zukuri houses, however, is longest in winter and zero in summer when the roof gap faces due north. When the gap faces the actual north-northeast direction, the depth in winter is shorter all morning, but is kept at 1.4 meters and above. In the cases of the northeast and east, the depths are much shorter in winter and the direct sunlight enters the room in summer. Consequently, the kudo-zukuri houses have good balance between wind enduring performance and sunlighting control due to their proper direction.
\end{abstract}

Keywords : Roof gap, Local climate, Wind rose, Wind name, Depth of direct sunlight area 屋根谷, 地域気候, 風配図, 風名, 日照到達距離

\section{1. 目的}

九州にはコ字に折れ曲がった寄棟屋根を持つクド造り民家が現在 も残されている。図 1 にクド造りの分布域 1)を示す。主に福岡県南 部の山間から熊本県西部、佐賀県の有明海沿岸部にかけて分布する。 とりわけ有明海北西岸の佐賀県鹿島市および周辺には、コ字に開い た屋根谷の部分が北北東を向いていることが多い2)。本研究の目的は、 この屋根谷方位の決定要因を立地地域の気候との関連の中に見いだ そうというものである。

\section{2. 既往研究の成果と課題}

クド造りの成立の背景として、幕府や藩による梁間の制限が挙げ られる。表 1 に梁間制限に関する主な家作禁令を示す34)。遅くとも 1643 年には武家に対し具体的に梁間を制限する記述が見られること から、商家や農家に対しても同等もしくはそれ以上に規制されてい たと考えられている ${ }^{3)}$ 。その後、徳川時代の長い太平の間に次第に形 骸化し 3)、繰り返し禁令が出されることになる。しかし佐賀において

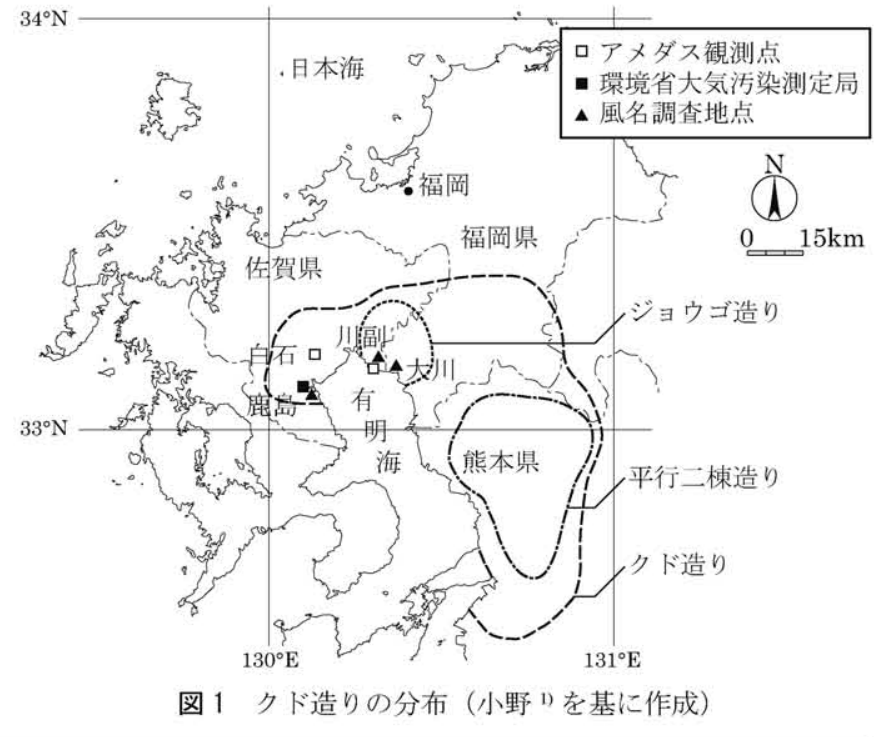

図 1 クド造りの分布（小野1)を基に作成）

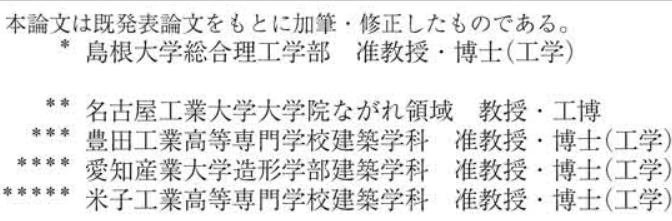

Assoc. Prof., Interdisciplinary Faculty of Science and Engineering, Shimane University, Dr. Eng.

Prof., NAGARE College, Nagoya Institute of Technology, Dr. Eng.

Assoc. Prof., Dept. of Architecture, Toyota National College of Technology, Dr. Eng. Assoc. Prof., Dept. of Architecture, Aichi Sangyo University, Dr. Eng. Assoc. Prof., Dept. of Architecture, Yonago National College of Technology, Dr. Eng. 
表 1 江戸期の主な家作禁令

\begin{tabular}{|c|c|c|c|c|}
\hline 発布年 & & 法度・禁令名 & 条文（抜粋） & 出典 \\
\hline 寛永 20 & (1643) & 徳川禁令考四 & $\begin{array}{l}\text { 一、萬石以下之面々雖為番頭、座敷二間半梁にすべからず、但臺所は三間梁不苦、有來候家を作直候時は } \\
\text { 右數を可用事 }\end{array}$ & 3) \\
\hline 明暦 3 & $(1657)$ & 徳川禁令考 & 一、作事候とも長屋は不及申、裹店居間の分も三間梁より大に作申間敷事 & 3) \\
\hline 寞文 8 & $(1668)$ & 武家嚴制録巻四 & $\begin{array}{l}\text { 寺院造作の御觸書條々 } \\
\text { 一、梁行京間三間を限るべし但桁行は心得次第たるべし }\end{array}$ & 3) \\
\hline 元禄 12 & (1699) & (不詳) & 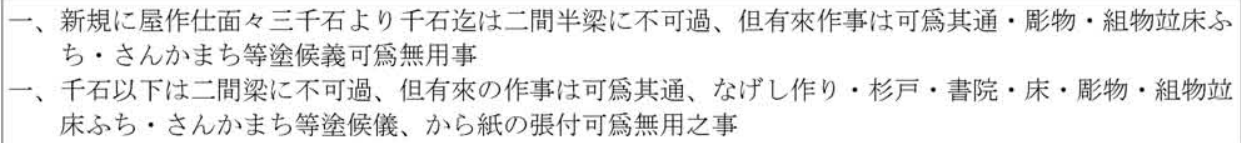 & 3) \\
\hline 享保 6 & $(1721)$ & 七十五箇條御法度書 & $\begin{array}{l}\text { 一、長押作之義有來候者差置き、建直し候節長押作無用に候、其外新規に建候家は梁間可限三間候、耕作 } \\
\text { の受無據仔細有之は役人方へ相達し可受指圖事 }\end{array}$ & 3) \\
\hline 天保 2 & $(1831)$ & 郷内諸法度 & $\begin{array}{c}\text { 一、家作の儀、庭家共二間に八間の住居を上にして、成丈手狭に相応々々に相整うべく候、風々付の床柱・ } \\
\text { 違棚・袋棚・なげし天井・目荒戸・唐紙立具・縁付睤・其外目立候品堅く停止せしめ候事 }\end{array}$ & 4) \\
\hline
\end{tabular}

は厳しく守られていたとされ ${ }^{56) 7}$ 、佐賀県文化財調査報告書に記さ れている約 200 棟のうち、ほとんどの農家の梁間が 2 - 2.5 間であり、 庄屋や武家等の上位層を含めても 3 間梁とするものは 10 数棟に限ら れる 5)8。このような梁間規制下で室面積の拡大を図るために、直屋 から角屋を出して鍵屋となり、さらに棟のもう片端から同方向に角 屋を出し両角屋の間を片流れ下屋で覆うようになって、クド造りの 形態に至ったと考えられているゅ。間取り形式は、広間型三間取り、 広間を前後に分割した四間取り、六間取り、下屋・角屋を出しさら に室数を増した間取りなど多様であるが、屋根谷は玄関正面の反対 側に向ける後谷型（裏谷型）が多数を占め、正面側に向ける前谷型 (表谷型) や横向きの横谷型は少ない5)。前谷型とすると屋根谷間の 下屋を正面に向けて見栄えがよくないことが理由の一つとして推察 されているす。見栄えという観点に立てば、もともと平入り直屋か らの発展であり、正面を直屋と同じように見せられる後谷型とする のは自然なことであったであろう。主に佐賀県南部に分布し 299、屋 根谷方位は北向き、特に有明海北西岸のものは北北東が多い2)。

一方、平行二棟造りが起源とされるものもある 1100 。平行二棟造り は、梁間 $2-2.5$ 間とする妻入りの居住棟と土間棟が並列し、互い の平同士を接して内部を一体化したもので、居住棟はザシキ・オマ エ (オモテ)・へヤと絴割りされた平面を基本形とする ${ }^{1111}$ 。両棟の 間は谷樋で繋がれ、その下部はテノマ(樋の間) と呼ばれる土間の

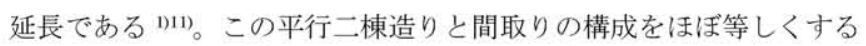
クド造りが数多く確認されており、二棟造りを起源とする説の根拠 となっている ${ }^{10 \%}$ 。クド造りとすることにより小屋組が一体化し構造 上有利となるだけでなく、谷樋が短くなり雨仕舞いを改善できるこ とも指摘されている $) 。$ 両棟の間隔を離し谷樋部が下屋に置き換え られれば、さらに室の拡大が可能となり雨仕舞いの問題も解消され ることとなる D。この段階に至ると、間取り・構造・外観とも鍵屋 を起源とするものと区別がつかなくなっていく ${ }^{10)}$ 。主に屋根谷方位 を南向きとした前谷型で、平行二棟造りが分布する熊本県北西部か ら福岡県南西部に多い 291910。妻入りを基本とする平行二棟造りの小 屋組を繋いでクド造りとしても、同じように妻入りになる前谷型と することは発展過程の中で必然であったと推察される ${ }^{10 \%}$

ジョウゴ造りは棟をコ字からさらに慗いでロ字にしたものである。 二棟造り・鍵屋のいずれを起源とするかは諸説あるが、少なくとも より強固な構造である点は指摘できるだろう ${ }^{12)}$ 。屋根中心部に集め
られた雨水は瓦樋で受け、小屋裏を通って外に排出しなければなら ないため、雨仕舞いはよくない。そのためか数は少なく、図 1 に示 すように、分布範囲は佐賀市川副町から福岡県柳川市にかけてのご く狭い地域に限られる。

平面が正方形に近く小屋組が一体となることで、クド造りやジョ ウゴ造りの構造が結果的により強固になった。軟弱地盤である有明 粘土層の地質域とクド造りの分布域がほぼ重なることから、地盤と の関係を指摘する説があるなど 1314)15)、クド造りの構造的優位は成 立起源に因らない特徵の一つと捉えられる。対してクド造りの屋根 谷方位については、成立起源によって異なる特徴の一つといえるだ ろう。あるいは分布の違いを考えれば、地域によって異なる特徵と 見ることもできる。九州の伝統的な農家住宅は玄関前である南側を 農作業場と寸る屋敷構えが一般的であることから、後谷型として北 側で雨水を処理し、特に干拓地などではクリークや池を設けて貯水

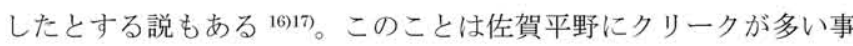
実とも矛盾しない。したがって、成立起源や雨水処理が要因である として、佐賀のクド造りに前谷型や横谷型ではなく後谷型が多いこ とは説明できる。しかしなお、後谷型の建物自身をやや東に振り向 けて屋根谷方位を北北東にするものが多く、真北や北東あるいは北 西が少ないことまでは説明できない。

一方で、クド造りは耐風性能に優れていると住民に認識されてい ることが過去の現地調查研究 ${ }^{6181819}$ によって指摘されており、本研究 の調査時にも住民から同様の証言を確認している。加えて、屋根谷 方位と立地地域の卓越風向との関連が既に示唆されている ${ }^{216) 。 し か ~}$ しながら、気象データ等による客観的裏付けを欠いており、卓越風 向との関連の有無については未だ明らかでないのが現状である。ま た、多くの場合、後谷型クド造りでは屋根谷下の下手後をチャノマ やダイドコロ (三間取りの場合はオモテ)、上手後をナンドやへヤな どと呼ばれる室とし、玄関横の下手前はオモテ、上手前は仏間や床 の間を持つザシキである。北面するチャノマ・ダイドコロ・ナンド が日常の生活空間であるのに対し、南面するオモテ・ザシキは来客 時や冠婚葬祭などの公的な空間であり、一般に北面する室に比して より陽当たりに配慮される。しかしながら、クド造り民家を対象に 南面する室内への日照について検討した例は希有というほかない。

したがって、有明海北西岸に位置する佐賀県鹿島市および周辺を 対象に、後谷型のクド造り民家の耐風性能および日照調節性能と屋 
根谷方位との関連を検証した。

\section{3. 耐風性能}

建物にかかる風圧力は速度圧と風力係数の積である。速度圧が風 向に依存しないのに対し、風力係数は建物の形状や風向によって異 なるため、クド造りの風力倸数を風向別に検討した。図 2 に平成 12 年建設省告示第 1454 号に基づいて概算した典型的なクド造り形態 の各構造面の風力係数を示す ${ }^{200}$ 。屋根面を持ち上げようとする吸引 力が最もかかる部分の面積（係数 -1.0）について、屋根谷を風向に 対して垂直に向ける場合 (図中) が最も狭く、風下に向ける場合 (図左)
がこれとほぼ同程度であるのに対し、風上に向ける場合（図右）は 前 2 条件よりも約 2 倍広い。局部的に吸引力がかかる出隅部も、風 上に向ける場合の方が多い。したがって、屋根谷を卓越風向に向け ることが而風面から見て好ましくないのは明らかである。

後谷型のクド造りが多く残る鹿島市および杵島郡白石町、ならび にジョウゴ造りの分布地域である佐賀市川副町を対象に、卓越風向 を調べた。鹿島や白石は、麦と米の二毛作が営まれる干拓地であり、 建物の方位決定に際し地理的制約は山間部のように大きくないと考 えられる地域である。風向風速デー夕は、鹿島（標高 $5 \mathrm{~m}$ 、風向風速 計の高さ地上 $7 \mathrm{~m}$ ) については環境省大気污染物質広域監視システ

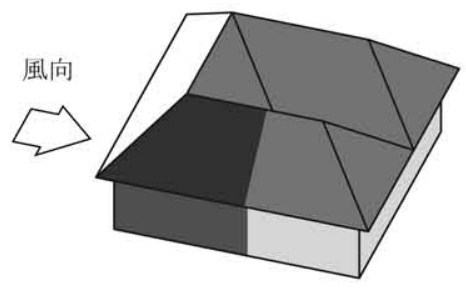

鹿島1月（1990-2004）2000は久測

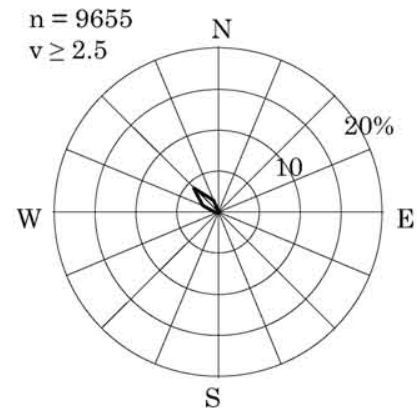

鹿島7月（1989-2004）1999は欠測

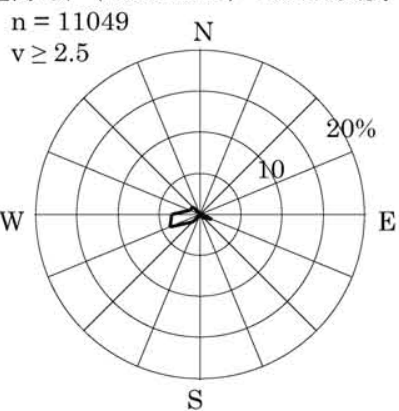

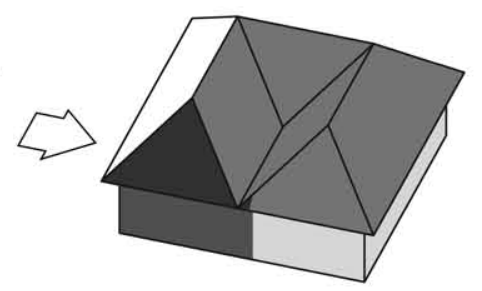
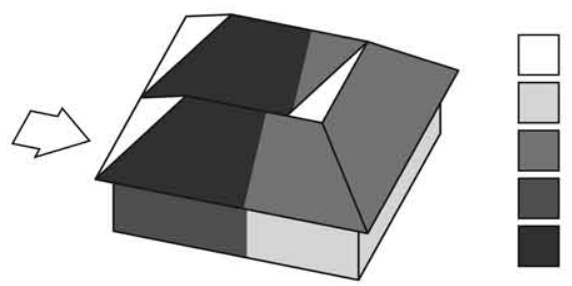

0.4

$-0.4$

$-0.5$

$-0.7$

$-1.0$

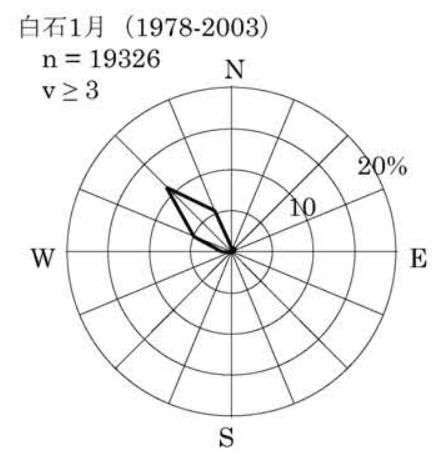

白石7月（1977-2003）

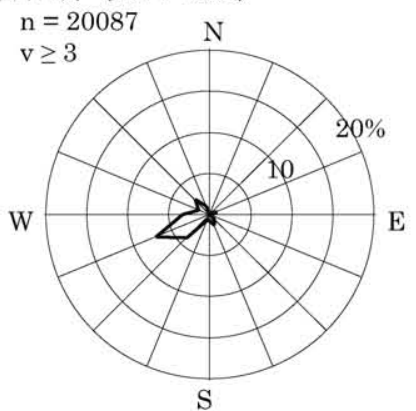

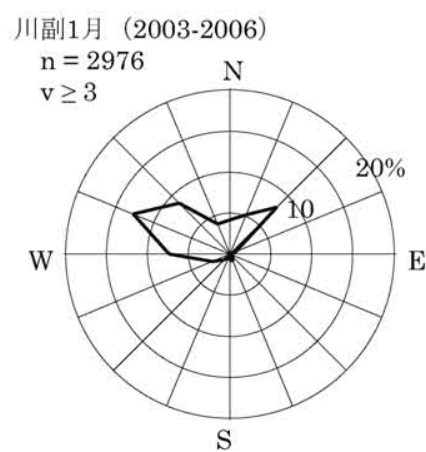

川副7月（2003-2006）

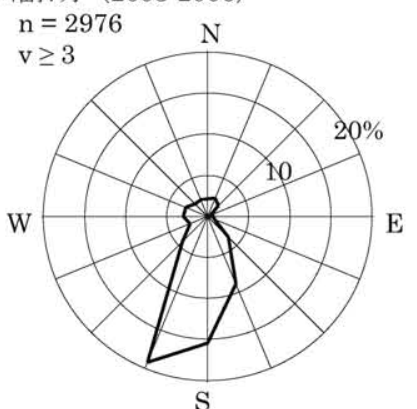

図 3 鹿島・白石・川副における風配図
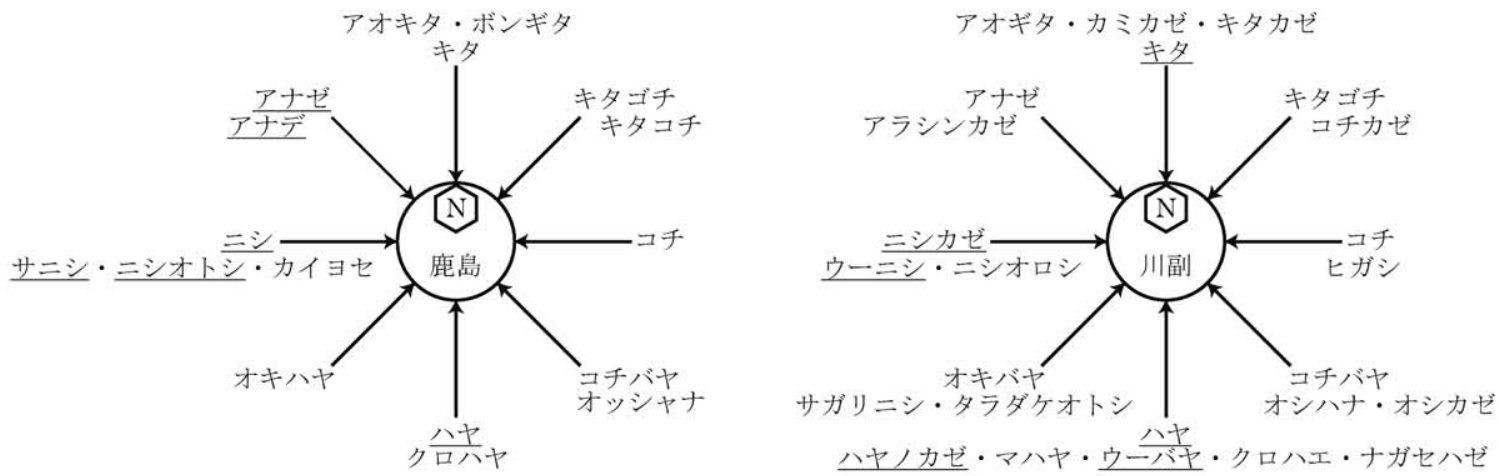

図 4 鹿島・川副における風向別の風名 
ム（AEROS、そらまめ君）の測定局における 1 時間値、白石（標高 $4 \mathrm{~m}$ 、風向風速計の高さ地上 $8 \mathrm{~m}$ ) と川副（標高 $2 \mathrm{~m}$ 、風向風速計の 高さ地上 $8.5 \mathrm{~m})$ については気象庁地域気象観測システム (AMeDAS、 アメダス）の観測所における 1 時間值を用いた注1)。図 1 に鹿島・白 石・川副における観測点の配置を、図 3 に鹿島・白石・川副におけ る 1 月および 7 月の風配図を示す。ただし、風速はそらまめ君では $0.1 \mathrm{~m} / \mathrm{s}$ 単位、アメダスでは $1 \mathrm{~m} / \mathrm{s}$ 単位で示されるため注2)、それぞれ $2.5 \mathrm{~m} / \mathrm{s}$ 以上、 $3 \mathrm{~m} / \mathrm{s}$ 以上について求めた。

図 3 より、鹿島・白石において、1月に卓越する風向は北西、次 いで北北西・西北西であり、他の方位についてはほとんど卓越しない。 7 月には西一南西にかけて卓越し、他の方位についてほとんど認め られない。一方で川副においては、1月には西一北西のほか、北東 風も卓越する。7 月には南南西一南南東の風が卓越する。

地域住民の風に対する認識を探るため、関口が 1980 年に主に漁 業従事者を対象に実施した風名調查の資料 ${ }^{21}$ )を分析した。これら風 名は単に風向だけでなく、季節や時間・程度、あるいは好まれる風 や危険な風を呼び分けている。図 1 に本研究で取り上げた風名調査 地点を、図 4 に鹿島および川副における風向別の風名を示す。図 4 において、好まれないと認識されている風名には下線を引いている。

図 4 より、鹿島においては、ニシ・アナゼ・アナデは冬の強くて 寒い西・北西風を指し、短時間だが危険とされる。ニシオトシも冬 の突風を指し、 3 月に吹く西風は特にサニシと呼び分ける。八ヤは 春夏に多く、家屋に風害をもたらすという。アオキタ・ボンギタは 8 -9月の秋野菜の種まき時期の北風、キ夕は秋冬の中程度の好漁 を呼ぶ風を指し、むしろ歓迎される風として認識されている。川副 においては、風速 $15 \mathrm{~m}$ 以上の西・南風をウーニシ・ウーバヤと呼び、 南から西にかけての風に対する意識は鹿島の場合と同様に強い様子 がうかがえる。しかし北風に対する認識は鹿島とやや異なっており、 アオギタは秋の晴天風であるが、キタは不漁を呼ぶ風を指寸。同じ くジョウゴ造りが残る大川においてもキタは冬の強風とされており、

表 2 玄関方位の南からの偏角・庇高・軒出の実測結果

\begin{tabular}{|c|c|c|c|c|}
\hline & 所在地 & 偏角 [ ${ }^{\circ}$ ] & 庇高 [m] & 軒出 [m] \\
\hline 1 & 多久市西多久町大字板屋 & 32 & 2.20 & 0.87 \\
\hline 2 & 多久市西多久町大字板屋 & 20 & 2.00 & 0.27 \\
\hline 3 & 多久市西多久町大字板屋 & 8 & 1.50 & 0.59 \\
\hline 4 & 多久市西多久町大字板屋 & 16 & 1.95 & 0.85 \\
\hline 5 & 杵島郡大町町福母. & 5 & 2.00 & 0.50 \\
\hline 6 & 杵島郡大町町福母 & 9 & 1.86 & 0.58 \\
\hline 7 & 杵島郡大町町福母 & 7 & 1.85 & 0.54 \\
\hline 8 & 鹿島市重ノ木 & 34 & 2.03 & 0.85 \\
\hline 9 & 鹿島市重ノ木 & 30 & 2.04 & 1.00 \\
\hline 10 & 鹿島市重ノ木 & 41 & 1.87 & 0.75 \\
\hline 11 & 鹿島市重ノ木 & 26 & 2.13 & 0.74 \\
\hline 12 & 鹿島市重ノ木 & 28 & 1.78 & 0.88 \\
\hline 13 & 鹿島市重ノ木 & 35 & 1.90 & 0.78 \\
\hline 14 & 鹿島市重ノ木 & 28 & 1.89 & 0.80 \\
\hline 15 & 鹿島市重ノ木 & 34 & 2.19 & 0.73 \\
\hline 16 & 鹿島市重ノ木 & 27 & 1.88 & 0.86 \\
\hline 17 & 鹿島市重ノ木 & 34 & 1.91 & 0.85 \\
\hline 18 & 鹿島市重ノ木 & 27 & 1.70 & 0.96 \\
\hline 19 & 鹿島市重ノ木 & 25 & 1.86 & 0.86 \\
\hline 20 & 鹿島市重ノ木 & 30 & 1.88 & 0.63 \\
\hline 21 & 杵島郡白石町樑浦 & -44 & 1.77 & 0.90 \\
\hline 22 & 杵島郡白石町樑浦 & 22 & 1.85 & 0.73 \\
\hline & 平均 & 22 & 1.91 & 0.75 \\
\hline
\end{tabular}

少なくとも歓迎される風とは認識されていないと捉えられる。

\section{4. 日照調節性能}

鹿島市および周辺地域に現存する後谷型クド造りのうち、調查協 力を依頼し承諾の得られた 22 軒を対象とした。このうち多久市にあ る 4 軒は牛津川とともに丘陵の合間を縫う県道 25 号多久若木線沿い に建つが、標高差が小さく平地部も比較的広いことから、屋根谷方 位の決定の際の地理的制約は大きくないと判断し分析に加えた。い ずれも建築年は不明であるが、茅莫きもしくは上からトタン等で被 覆されており、築後数十年は経過していると思われる。日照調節の 指標として、南面する室の床面最外部から室内に差し込む日差しの 深さ (以降、日照到達距離と称す) を求めた。2004 年 8 月に玄関方 位の南からの偏角を方位磁石にて、玄関横のザシキまたはオモテの 室前の軒出・庇高を巻尺にて実測した。偏角については、すべて後 谷型を対象としているため、屋根谷方位の北からの偏角と一致する ものとして取り扱った。軒出・庇高については、全国の伝統民家の 間取り調查資料を検尺した雲井ら 22) の方法に倣い、それぞれ最外部 の柱の外面から庇先まで・床面から庇の最下端までとした。表 2 に 各対象家屋の実測結果を示す。得られたデータおよび各対象家屋が 立地する緯度・経度より、日照到達距離を算出した。図 5 に冬至及 び夏至における日照到達距離を全調査家屋の平均として示す。これ らの家屋の屋根谷を真北・北東・真東（すなわち玄関方位を真南 · 南西・真西）に向ける場合についても同時に示している。

表 2 より、1 軒を除いて屋根谷は真北よりも東に振れている。ほ ぼ北である $5^{\circ}$ からほぼ北東である $41^{\circ}$ まで分布するが、半数以上 が北北東に区分され立3)、平均ではほぼ北北東を指す $22^{\circ}$ である。庇 高・軒出の平均はそれぞれ $1.91 \mathrm{~m} \cdot 0.75 \mathrm{~m}$ である。

図 5 より、屋根谷を真北に向けた場合、冬至には終日 $2.1 \mathrm{~m}$ を超 える日照到達距離が得られる。夏至には終日にわたり室内に直達日 射は届かない。対象家屋 22 軒の平均の場合、冬至における日照到達
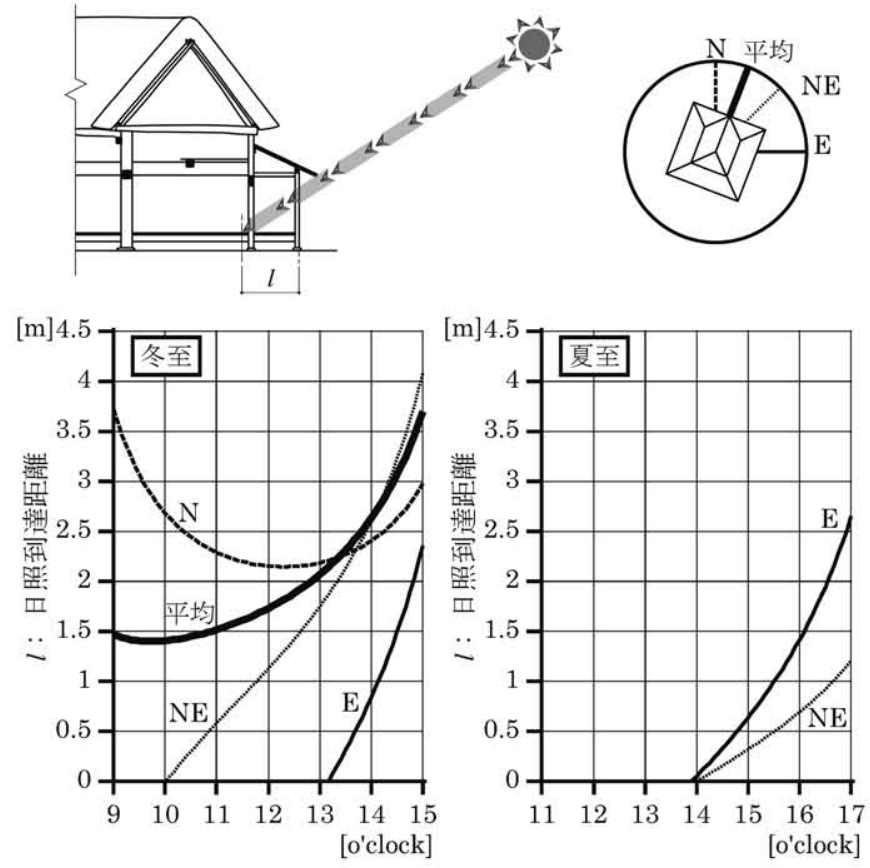

図 5 冬至・夏至における南面する室への日照到達距離 
距離は 13 時頃まで、屋根谷を真北に向ける場合より短い。それでも 終日 $1.4 \mathrm{~m}$ 以上を確保している。夏至においても室内に直達日射は 届かず、うまく日照が調節されている。しかしさらに東に振れ屋根 谷が北東・真東になると、冬至の日照導入は明らかに悪化し、夏至 においても 14 時以降に西日が差し込むことがわかる。

なお、雲井ら ${ }^{22)}$ による佐賀の 22 軒注4) の庇高・軒出の平均はそれ ぞれ $1.88 \mathrm{~m} \cdot 1.38 \mathrm{~m}$ であった。また、冬至における日照到達距離は 本調查と同様、終日 $1.4 \mathrm{~m}$ 以上を確保していた。したがって、時代 が下り軒出が浅く変化してきた傾向が賽えるものの、クド造りの日 照調節性能の経年変化は大きくないと考えられる。

\section{5. 耐風性能と日照調節性能の相互関係}

鹿島・白石などの後谷型の分布域では、冬季に北西方向、夏季に 西一南西の強風が吹くのに対し、北東一東からはあまり強風は吹か ない。そのため耐風面から見れば、屋根谷は北東一東に向けた方が 都合が良いことになる。住民も北西一西の強風を危険と認識してい る一方で、北一東の風に対して危険との認識もあまりない。そのた め後谷型である北向きから、少しでも北西風に耐えるために、屋根 谷を東に向けたのではないかと考えることができる。しかし耐風上 最も都合が良い北東まで振り向けると、夏の日照遮蔽・冬の日照導 入が十分とはいかなくなる。日照調節面から見れば、屋根谷方位は 真北に近いほど都合が良いが、北北東であれば、真北には及ばない ものの冬の日照導入をある程度確保しつつ、夏の直達日射も遮るこ とができる。したがって、耐風と日照調節の両面で許容できる屋根 谷方位として、北北東が自ずと選ばれるようになったのではないだ ろうか。少なくとも、佐賀県有明海北西岸のクド造りにとって、北 北東が耐風と日照調節のバランスの最も良い屋根谷方位であること は明らかである。同様に考えれば、冬に北一北東からも強風が吹き、 北風も好まれない川副では、風向による耐風性能の差を小さくする ためにジョウゴ造りが生まれたと推察することができよう。

\section{6. 結論}

本調査時に住民に対し現在の屋根谷方位とした理由を尋ねたとき には、「わからない」「知らない」「さあ…といった曖昧なものがほ とんどで、風と日照が動機付けとなったことを示す直接的な回答が 得られていた訳ではない。それでも、クド造りの耐風性能に対する 認識は明らかにあり、風そのものに対する意識も風名といった言語 文化に映し出されるほどはっきりしていた。にもかかわらず、建物 自身を振り向けて屋根谷を北東にする例は少なく、東まで振るもの は本調查や文献資料 ${ }^{23}$ によっても確認できなかった注5。このことは、 風だけでなく表側の空間への日照に対する配慮がはたらいていたこ とのあらわれであるとしても、なんら不自然ではないであろう。し たがって、クド造りの風と日照に対する適応性能は、気候を除いた 他の要因によって方位が決められた結果として偶然に得られたので はなく、地域気候もまた方位決定の一因であり、合目的的に獲得さ れたと考えられる。

すなわち、佐賀県有明海北西岸のクド造りの屋根谷方位は、その 成立起源や雨水処理の都合から北向きを基本としつつ、耐風と日照 調節の両面を考慮して北北東に向けられるようになったと結論され る。

\section{謝辞}

実測調査にご協力いただいたクド造りの住民の方々、鹿島市の気 象データを提供いただいた佐賀県くらし環境本部環境課長に深謝し ます。本研究の研究費の一部に文部科学省科学研究費補助金 (若手 研究（B）No. 14750494）を使用した。

\section{本論文に関する既発表論文}

1）長野和雄、堀越哲美、宇野勇治、兼子朋也、鈴木健次 : 有明海沿岸に分布 するクド造り民家の気候適応性能調査, 第 28 回人間一生活環境系シンポジ ウム報告集, pp. 77-80, 2004

2) Nagano K., Horikoshi T., Uno Y., Kaneko T. and Suzuki K.: Bioclimatic design of traditional vernacular houses in Japan: climatic factors to determine orientation of the kudo-zukuri houses in Saga, 17th International Congress of Biometeorology, Vol. 1, pp. 196-199, 2005

注

注 1) 白石については、2005 年気象観測統計指針による再計算前のデータで ある、アメダス観測年報（1976-2001）・アメダス年報（2002-2003）（気象 庁編集・財団法人気象業務支援センター発行）を用いた。川副については、 気象庁ホームページ (www.data.jma.go.jp) の公開データを用いた。

注 2) アメダスデータ等統合処理システムの運用開始に伴い、白石では 2008 年 3 月 26 日、川副では 2009 年 1 月 29 日より、風速の表示単位が $1 \mathrm{~m} / \mathrm{s}$ か ら $0.1 \mathrm{~m} / \mathrm{s}$ に変更されたが、本研究はそれ以前の期間を分析対象としている。 注 3） 16 方位表示の場合、屋根谷方位が北北東に区分される範囲は $11.25-$ $33.75^{\circ}$ であるが、偏角の実測值は精度上、 $1^{\circ}$ 単位で求めている。そのため $34^{\circ}$ である 3 軒は爰密には 33.50 - $34.49^{\circ}$ の範囲内にあり、北北東に区分 されるか否か判然としない。したがって、本調査の対象家屋 22 軒のうち、 最大で 15 軒、最小でも 12 軒が北北東に区分されることになる。

注 4）雲井ら（文献 22）は佐賀県文化財調查報告書に平面・断面・方位が明 記されているものを対象としており、クド造りだけでなく、直屋・鍵屋も含 めている。しかし改めて同報告書所収の図面を確認したところ、直屋·键屋・ クド造りの違いによって庇高·軒出が異なる傾向は認められなかった。なお、 本研究が対象とした 22 軒とは重複していない。

注 5）建物ごと振って屋根谷を東、表側すなわち玄関方位を西に向けるものを 指す。玄関方位を南のままに屋根谷を東に向けた横谷型は少数ながら確認で きる。

\section{参考文献}

1）小野重郎：九州の民家 有形文化の系譜（上), 慶友社, pp. 172-179, 1982

2）坂田明京美, 秋山晴子：九州民家における地方性, 民俗建築, No. 88, pp. 21-26, 1985

3）藤田元春：増補日本民家史，刀江書院，pp. 448-468, 1937

4）小城町史編集委員会: 小城町史, pp. 247-250, 1974

5）青山賢信 : 第 5 章 平入曲家の間取及び屋根構造の発展,「佐賀県文化財 調査報告書第 31 集 佐賀県の民家」，佐賀県教育委員会, pp. 20-28, 1974

6）杉本尚次：九州地方の民家, 明玄書房, pp. 81-86, 1977

7）原田聰明：くど造り，「図説民俗建築大事典」日本民俗建築学会 (編), 柏 書房, pp. 150-151, 2001

8）佐賀県教育委員会：佐賀県民家調查家屋一覧表，「佐賀県文化財調查報告 書第 31 集 佐賀県の民家」, 佐賀県教育委員会, 附表 pp. 1-13, 1974

9）澤村仁：民家と町並 九州・沖縄，日本の美術，至文堂，No. 290, pp. 24-45, 1990

10）青山賢信 : 第 6 章 縦割系曲家農家の間取と構造の発展,「佐賀県文化財 調查報告書第 31 集 佐賀県の民家」, 佐賀県教育委員会, pp. 29-41，1974

11）原田聰明：二棟造り,「図説民俗建築大事典」日本民俗建築学会 (編), 柏 書房, pp. 152-153, 2001

12）杉本尚次 : 九州地方の民家, 明玄書房, pp. 86-89, 1977

13）橋本慎蔵：民家「クド造り」「ジョーゴ造り」の発生原因について，日本 建築学会大会学術講演梗概集 (関東), 計画系, pp. 2519-2520, 1984 14）佐藤正彦:九州地方の民家,「図説民俗建築大事典」日本民俗建築学会 (編), 
柏書房, pp. 318-321，2001

15）佐賀県立博物館：展示資料，2004.8

16）橋本慎蔵, 青木正夫, 廣岡利貞, 竹下輝和, 益田信也：民家「クド造り の工学的考察 その 4 屋敷の「水領域」と屋根の谷方向の関倸について (1), 日本建築学会大会学術講演梗概集 (近畿), F, pp. 965-966, 1987

17）大坪昌裕，橋本慎蔵，青木正夫，廣岡利貞，竹下輝和，益田信也：民家「ク ド造り」の工学的考察 その 5 屋敷の「水領域」と屋根の谷方向の関倸 について (2), 日本建築学会大会学術講演梗概集 (近畿), F, pp. 963-964, 1987

18）太田静六 : 福岡県の民家とその周辺，九州大学工学部建築教室建築様式史 研究室, pp. 112-115, 1973

19）佐賀県建築士会 : 佐賀県-くど造り-, pp. 3-11，1979

20）建築申請実務研究会: 建築申請 memo, 新日本法規, No. 38, pp. 4-7, 2001

21）関口武: 風の事典, 原書房, pp. 147-944, 1985

22）雲井信広，堀越哲美，宇野勇治：伝統的住宅における軒と庇の日照調整 効果に関する研究, 日本建築学会大会学術講演梗概集 (関東), E-2, pp. 239-240, 2001

23）佐賀県教育委員会：図面，「佐賀県文化財調查報告書第 31 集 佐賀県の 民家」，佐賀県教育委員会，図面 pp. 1-97，1974

(2009年 9 月 7 日原稿受理，2009年12月14日採用決定） 